\title{
Nano Copper Ferrite Catalysed Improved Procedure for One-Pot Synthesis of Poly Substituted Pyridine Derivatives
}

\author{
S. PAUL DOUGLAS*, B. SWATHI, M. RAVI KUMAR, Y. RAMESH, \\ K. JAYA RAO, B. SATYANARAYANA and CH. PANDU NAIDU \\ Department of Engineering Chemistry, A.U. College of Engineering [A], \\ Andhra University, Visakhapatnam-530 003, Andhra Pradesh, India \\ spauldouglas.engchem@auvsp.edu.in
}

Received 29 December 2015 / Accepted 20 January 2016

\begin{abstract}
The studies on application of magnetically separable substituted nano ferrites towards the multicomponent one-pot synthesis of heterocyclic compounds were thoroughly investigated. The present study gives an efficient method for the one-pot three-component synthesis of poly substituted pyridine derivatives by the cyclo-condensation of aromatic aldehyde, malononitrile and substituted phenols in the presence of magnetically recoverable nano copper ferrite catalyst. This method involves improved advantages like low percentage of catalyst used, lesser reaction times, higher yields, magnetic recoverability and reuse of the catalyst, which makes it an environmentally benign process.
\end{abstract}

Keywords: Nano copper-ferrite, Magnetically separable catalyst, One-pot multi-component synthesis, Poly substituted pyridines

\section{Introduction}

Multi-component reactions [MCRs] play a significant role in the organic synthesis particularly in the synthesis of medicinally potent heterocyclic compounds. It involves a simple workup procedure for the synthesis of medicinally privileged scaffolds by the combination of two or more components in a single step process. Thereby it offers a great advantage over convergent, combinatorial and multistep synthesis ${ }^{1-3}$.

The poly substituted pyridine moiety has been identified as key constituent in many naturally occurring and synthetic biological active pharmaceuticals ${ }^{4}$. Among these pyridine derivatives of 2-amino-pyridine-3,5-dicarbonitrile skeleton have great importance as medicinally active compounds like antiprion ${ }^{5}$, antibacterial ${ }^{6}$, anti-biofilm ${ }^{6}$, anti-infective ${ }^{6}$, anticancer $^{7}$ and anti-hepatitis- $B^{8}$. Penta-substituted pyridine moiety is a medicinally privileged scaffold useful in the potassium channel opening for the treatment of urinary incontinence ${ }^{9}$ and the treatment for Creutzfeldt-Jakob disease, Parkinson disease, Hypoxia, Asthma, kidney disease and Epilepsy ${ }^{10-12}$. The importance of this class of compounds can be understood by the number of patents filed in recent years ${ }^{6-9}$. 
Due to vast range of biologically active poly substituted pyridine frameworks, they attract much attention in their synthesis. A number of procedures were carried out for the synthesis of poly-substituted pyridine derivatives using various synthetic procedures such as Diels-Alder reaction of 3-siloxy-1-aza-1,3-butadiene with 6-alkyl-3,5-dichloro-2 $\mathrm{H}$-1,4-oxazin-2-one with different types of acetylenic compounds ${ }^{13},[4+2]$ cycloaddition of oximinosulphonates ${ }^{14}$, Vilsmeier-Haack reaction of $\alpha$-hydroxy ketene dithioacetals ${ }^{15}$, Ruthenium-catalysed cycloisomerisation of 3 -azadienynes ${ }^{16}$ and $6 \pi$-azaelectrocyclization of azatrienes ${ }^{17}$ which limit with conventional multi-step process, low yield and challenging work up procedures.

Afterward a first convenient and interesting synthetic methodology reported for the onepot synthesis of poly-substituted pyridine derivatives by the cyclocondensation of aromatic aldehyde, malononitrile and thiophenol using $\mathrm{Et}_{3} \mathrm{~N}$ or 1, 4-diazabicyclo[2.2.2]-octane [DABCO] as catalyst ${ }^{18}$. Then a few MCR methods have been reported for the one-pot synthesis of poly substituted pyridine derivatives by the three component condensation of aromatic aldehyde, malononitrile and thiophenol in presence of various catalysts like $\mathrm{K}_{2} \mathrm{CO}_{3}$ under reflux ${ }^{19}$, Ionic liquid 1- $n$-butyl-3-methylimidazolium hydroxide [bmIm] $\mathrm{OH}^{20}$, Nano crystalline $\mathrm{MgO}^{21}$, Ammonium hydroxide ${ }^{22}$, TBAH [tetra butyl ammonium hydroxide] and Piperdine $^{23}$. The above reported methods have their own importance and merits. But these methods limit in their longer reaction times, low yields, use of toxic chemicals and nonrecoverability of the catalyst. Hence there is a necessity to develop newer, greener, effective and environmental friendly methods of synthesis of poly substituted pyridine derivatives. It is further observed that in the above reported methods ${ }^{18-23}$ thiophenol has been used as a reactant but substituted phenolic derivatives such as 2-amino-6-phenoxy-pyridine-3, 5dicarbonitrile derivatives have not been reported.

Nano copper ferrite has earlier been used as magnetically separable catalyst for several organic synthetic reactions such as asymmetric hydrosilylation of ketones ${ }^{24}$, synthesis of diaryl or aryl alkyl sulfides via cross coupling process under ligand free conditions ${ }^{25}$, synthesis of substituted benzoxazoles via Ullmann-type coupling under ligand free conditions $^{26}$, cross- coupling of aryl halides with diphenyl diselenide ${ }^{27}$, green one-pot three component synthesis of spirooxindoles ${ }^{28}$, multicomponent synthesis of 1,4-di substituted 1,2,3-triazoles in tap water ${ }^{29}$ and synthesis 1,4 dihydro pyridines involving aromatic aldehyde, ethylacetoacetate and ammonium acetate ${ }^{30}$.

As a part of our ongoing research towards the synthesis of biologically active heterocyclic compounds using magnetically separable nano catalysts ${ }^{31}$, keeping environmental friendly methods in mind, here we are reporting an efficient improved procedure for one-pot multicomponent synthesis of some new poly substituted pyridine derivatives by condensation of aromatic aldehyde, malononitrile and substituted phenols using nano copper ferrite as a catalyst (Scheme 1). This methodology involves high catalytic activity of the catalyst, its magnetic recoverability and reuse for five cycles without any noticeable loss of its catalytic activity.

\section{Plausible mechanism for the scheme of the reaction}

A plausible mechanism had been proposed for the catalytic activity of the reaction. It can be predicted from the mechanism (Scheme 2) that it follows a base catalyzed pathway. The reaction is initiated by ferrite-mediated Knovenagel condensation of aldehyde and malononitrile, generating cinnamonitrile(1), which reacts with another molecule of malononitrile producing dihydropyridine intermediate (2). Then there are two possibilities to oxidize dihydropyridine to pyridines (3), one is aerobic oxidation of dihydropyridine, which plays a minor role limited by the solubility of oxygen in reaction solvent [ethanol] and the other is an efficient path, 
which involves hydrogen transfer from the dihydropyridine intermediate (2) to the Knovenagel intermediate (1). This step causes the involvement of an extra equivalent of aldehyde and malononitrile to get quick good yield of the product ${ }^{19,22,23}$.

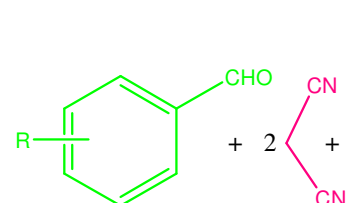

(1)

(2)

$$
\mathrm{R}=\mathrm{H}, 4-\mathrm{OCH}_{3}, 4-\mathrm{F}, 3-\mathrm{NO}_{2} \text {, }
$$

3,4 di- $-\mathrm{OCH}_{3}, 4-\mathrm{CH}_{3}$

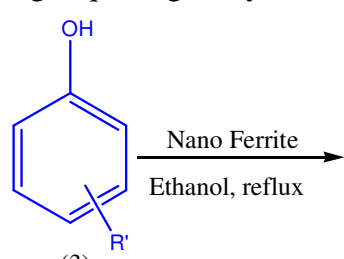

(3)

$\mathrm{R}^{\prime}=\mathrm{H}, 4-\mathrm{NO}_{2}, 4-\mathrm{Cl}$<smiles>[R][Tl]c1cccc(Oc2nc(N)c(C#N)c(-c3ccccc3)c2C#N)c1</smiles>

(4a-4j)

2-Amino-6-phenoxy-4-phenylpyridine3,5-dicarbonitrile

Scheme 1. Synthesis of substituted pyridine derivatives using aromatic aldehyde, malononitrile and substituted phenols using nano copper ferrite as catalyst

Copper Ferrite $\longrightarrow \mathrm{Cu}^{+2} \mathrm{O}^{-2} \mathrm{Fe}^{+3}{ }_{2} \mathrm{O}_{3}^{-2}$
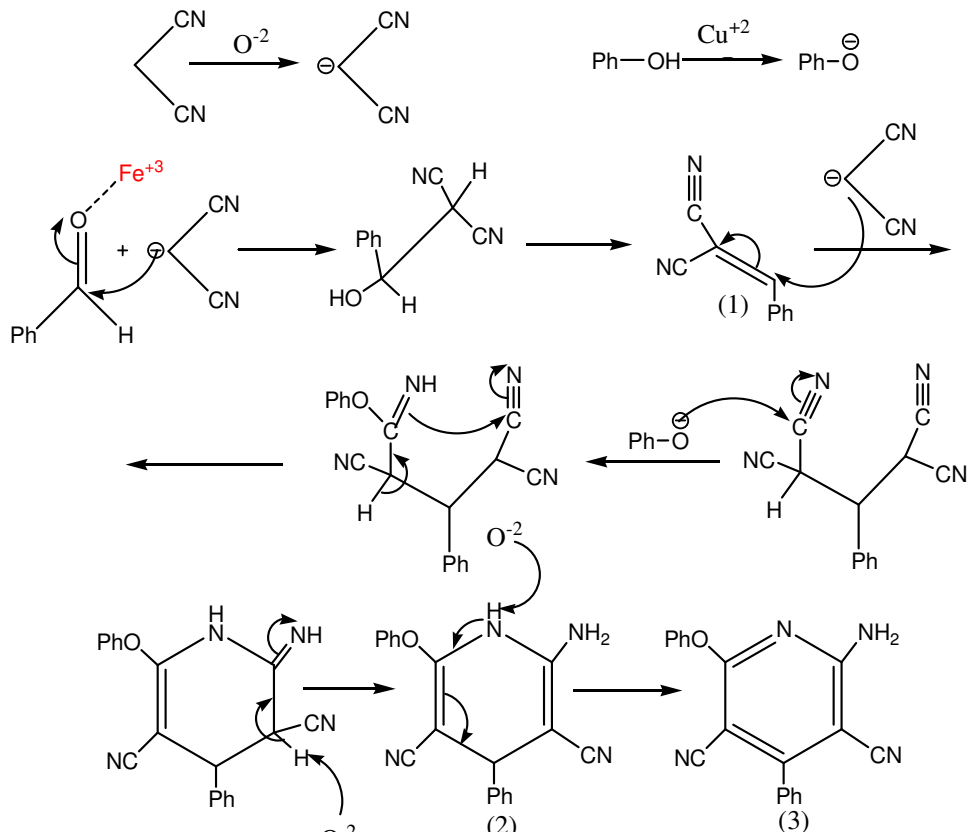

$\mathrm{O}^{-2}$

(2)

(3)

Scheme 2. Plausible mechanism for the formation of pyridine derivatives

\section{Experimental}

All chemicals were purchased from commercial sources and liquid aromatic aldehydes and liquid aromatic phenols are purified by distillation prior to use. XRD spectra were recorded on PANalytical-XPert pro diffractometer and the average crystallite size was determined from the corresponding XRD data. The microstructural morphology was studied with a Scanning Electron Microscope (SEM) model JEOL-JSM 6610 LV. FTIR spectra were recorded 
on BRUKER ALPHA FT-IR with Opus 6.1 version. Magnetization $\mathrm{M}[\mathrm{H}]$ measurements were made using a commercial vibrating sample magnetometer (VSM) model BHV-50 of Riken Denshi Co. Ltd. Japan. Specific surface area (SBET) of samples was determined by BET surface area analyzer (Nova 2000 series, Quanta chrome Instruments, UK). ${ }^{1} \mathrm{H}$ NMR spectra were recorded on the Bruker-Avance $300-\mathrm{MHz}$ spectrometer in $\mathrm{CDCl}_{3}$. The chemical shift values were reported on the $\delta$ scale in parts per million (ppm), downfield from tetramethylsilane (TMS) as an internal standard. The mass spectrum was recorded using a Perkin-Elmer PE SCIEX-API 2000, equipped with ESI source used online with a HPLC system after the ultraviolet (UV) detector. Silica gel used for column chromatography was purchased from ACME Chemical Company. All reactions were monitored by thin layer chromatography (TLC) on pre-coated silica gel $60 \mathrm{~F}_{254}$ (Merck) and spots were visualized with UV light.

\section{Catalyst preparation and characterization}

Magnetic spinel nano copper ferrite catalyst with composition $\mathrm{CuFe}_{2} \mathrm{O}_{4}$ was chosen for this study. For the preparation of the catalyst, aqueous solutions of stoichiometric amounts of copper nitrate along with ferric citrate were reacted with citric acid in 1:1 molar ratio. $\mathrm{pH}$ of the solution was increased to 7 by addition of ammonia to complete the reaction and ethanediol was added. The solution was evaporated very slowly over a period of ten to twelve hours to dryness. Viscosity and colour changed as the solution turned into a puffy and porous dry gel. As soon as the solvent removal completed, dried precursor underwent a self-ignition reaction to form a very fine powder known as as-synthesized powder. The as synthesized powder, thus obtained was calcined in a muffle furnace at $500{ }^{\circ} \mathrm{C}$ for 2 hours to remove the residual carbon and furnace cooled. The characteristics of the catalyst were reported by $\mathrm{us}^{31}$ and the copper ferrite was obtained in nano size $(\sim 30 \mathrm{~nm})$, crystalline in nature and having a large surface area of $127 \mathrm{~m}^{2} / \mathrm{g}$.

\section{General procedure for the synthesis of poly substituted pyridine derivatives}

The one-pot synthesis of poly substituted pyridine derivatives was carried out in a $250 \mathrm{~mL}$ round bottomed flask and fixed with a reflux condenser in an oil bath with temperature control and refluxed. About $500 \mathrm{mg}$ of the catalyst was taken and activated at $500{ }^{\circ} \mathrm{C}$ for $2 \mathrm{~h}$ and cooled to room temperature before the experiment. Aromatic aldehyde $(5 \mathrm{mmol})$ and malononitrile $(10 \mathrm{mmol})$ were mixed together along with the catalyst and $5 \mathrm{~mL}$ of ethanol then the contents are stirred for $15 \mathrm{~min}$ at $50{ }^{\circ} \mathrm{C}$. Afterwards the substituted phenol $(5 \mathrm{mmol})$ was added to the reaction mixture and refluxed. The completion of the reaction was monitored by TLC ( $n$-hexane: ethyl acetate $2: 1$ ) and the products were isolated by removing the catalyst magnetically from the reaction mixture. All the products were identified by FTIR, ${ }^{1} \mathrm{H}$ NMR and mass spectra of representative compounds and compared.

\begin{tabular}{|c|c|}
\hline Compound & Spectral data \\
\hline $\begin{array}{c}\text { 2-Amino-4-(phenyl)-6-phenoxy pyridine-3, } \\
\text { 5-dicarbonitrile (4a) }\end{array}$ & $\begin{array}{l}\text { Yellow solid; IR }\left(\mathrm{KBr}, \mathrm{cm}^{-1}\right): 3368(\mathrm{~N}-\mathrm{H}, \\
\text { str), } 3077(\mathrm{Ar}-\mathrm{CH}, \mathrm{str}), 2223(\mathrm{C}-\mathrm{N}, \mathrm{str}), \\
1642(\mathrm{C}=\mathrm{C}, \mathrm{str}), 1591(\mathrm{C}=\mathrm{N}, \mathrm{str}), 1491 \\
(\mathrm{C}-\mathrm{O}-\mathrm{C}, \mathrm{str}) \mathrm{cm}^{-1} ;{ }^{1} \mathrm{H} \text { NMR }\left(\mathrm{CDCl}{ }_{3}, \mathrm{ppm}\right) \\
\delta=7.26\left(\mathrm{~s}(2 \mathrm{H}), \mathrm{NH}_{2}\right), 7.92-7.90(\mathrm{~m}(2 \mathrm{H}), \mathrm{Ar}- \\
\mathrm{H}), 7.87(\mathrm{~s}(1 \mathrm{H}), \mathrm{Ar}-\mathrm{H}), 7.63(\mathrm{~m}(2 \mathrm{H}), \mathrm{Ar}-\mathrm{H}), \\
7.56-7.54(\mathrm{~m}(2 \mathrm{H}), \mathrm{Ar}-\mathrm{H}), \quad 7.782(\mathrm{~m}(1 \mathrm{H}), \\
\text { Ar-H); Mass: } \mathrm{m} / z 313\left(\mathrm{M}^{+}+1\right) ; \mathrm{C}_{19} \mathrm{H}_{12} \mathrm{~N}_{4} \mathrm{O} .\end{array}$ \\
\hline
\end{tabular}


<smiles>COc1ccc(-c2c(C#N)c(N)nc(Oc3ccc([N+](=O)[O-])cc3)c2C#N)cc1</smiles>

2-Amino-4-(4-methoxyphenyl)-6-(4-nitrophenoxy) pyridine-3, 5-dicarbonitrile (4b)<smiles>N#Cc1c(N)nc(Oc2ccccc2)c(C#N)c1-c1ccc(F)cc1</smiles>

2-Amino-4-(4-fluorophenyl)-6-phenoxy pyridine-3, 5- dicarbonitrile (4c)<smiles>N#Cc1c(N)nc(Oc2ccc([N+](=O)[O-])cc2)c(C#N)c1-c1cccc([N+](=O)[O-])c1</smiles>

2-Amino-4-(3-nitrophenyl)-6-(4-nitrophenoxy) pyridine-3, 5-dicarbonitrile (4d)<smiles>COc1ccc(-c2c(C#N)c(N)nc(Oc3ccc([N+](=O)[O-])cc3)c2C#N)cc1OC</smiles>

2-Amino-4-(3, 4-dimethoxyphenyl)-6-(4nitrophenoxy) pyridine-3, 5-dicarbonitrile (4e)<smiles>COc1ccc(-c2c(C#N)c(N)nc(Oc3ccccc3)c2C#N)cc1OC</smiles>

2-Amino-4-(3, 4-dimethoxyphenyl)-6phenoxy pyridine-3, 5-dicarbonitrile (4f)
Yellow solid; IR $\left(\mathrm{KBr}, \mathrm{cm}^{-1}\right): 3371(\mathrm{~N}-\mathrm{H}$, str), 3028 (Ar-CH, str), 2222 (C-N, str), 1572 $(\mathrm{C}=\mathrm{C}, \mathrm{str}), 1454(\mathrm{C}=\mathrm{N}, \mathrm{str}), 1446(\mathrm{C}-\mathrm{O}-\mathrm{C}$, str), $\mathrm{cm}^{-1} ;{ }^{1} \mathrm{H}$ NMR $\left(\mathrm{CDCl}_{3}, \mathrm{ppm}\right) \delta=7.26$ $\left(\mathrm{s}(2 \mathrm{H}), \mathrm{NH}_{2}\right), 8.17-8.16$ (m(2H), Ar-H), 7.92$7.90(\mathrm{~m}(2 \mathrm{H}), \mathrm{Ar}-\mathrm{H}), \quad 7.023 \quad(\mathrm{~m}(2 \mathrm{H}), \mathrm{Ar}-\mathrm{H})$, 6.91-6.90 (m(2H), Ar-H), $3.918\left(\mathrm{~s}(3 \mathrm{H}), \mathrm{CH}_{3}\right)$; Mass: $m / z 388\left(\mathrm{M}^{+}+1\right) ; \mathrm{C}_{20} \mathrm{H}_{13} \mathrm{~N}_{5} \mathrm{O}_{4}$.

Yellow solid; IR $\left(\mathrm{KBr}, \mathrm{cm}^{-1}\right): 3375(\mathrm{~N}-\mathrm{H}$, str), 3042 (Ar-CH, str), 2230 (C-N, str), 1595 (C=C, str), 1509 (C=N, str) 1338 (C$\mathrm{O}-\mathrm{C}$, str) $\mathrm{cm}^{-1} ;{ }^{1} \mathrm{H} \mathrm{NMR}\left(\mathrm{CDCl}_{3}, \mathrm{ppm}\right): \delta=$ 7.74(s $\left.(2 \mathrm{H}), \mathrm{NH}_{2}\right), \quad 7.963(\mathrm{~m}(2 \mathrm{H}), \quad \operatorname{Ar}-\mathrm{H})$, 7.26-7.22(m(5H), Ar-H), 7.745(m(2H), Ar$\mathrm{H})$; Mass: $m / z 331\left(\mathrm{M}^{+}+1\right) ; \mathrm{C}_{19} \mathrm{H}_{11} \mathrm{~N}_{4} \mathrm{OF}$.

Yellow solid; IR $\left(\mathrm{KBr}, \mathrm{cm}^{-1}\right): 3371(\mathrm{~N}-\mathrm{H}$, str), 3107 (Ar-CH, str), 2226 (C-N, str), $1612(\mathrm{C}=\mathrm{C}$, str), 1528 (C=N, str), 1383 (C$\mathrm{O}-\mathrm{C}$, str) $\mathrm{cm}^{-1} ;{ }^{1} \mathrm{H} \mathrm{NMR}\left(\mathrm{CDCl}_{3}, \mathrm{ppm}\right): \delta=$ 7.26( $\left.(2 \mathrm{H}), \mathrm{NH}_{2}\right), 8.662(\mathrm{~s}(1 \mathrm{H}), \mathrm{Ar}-\mathrm{H})$, 8.474-8.32(m(3H),Ar-H), 7.8-7.804 (m(4H),Ar-H);Mass: $\quad m / z \quad 403 \quad\left(\mathrm{M}^{+}+1\right)$; $\mathrm{C}_{19} \mathrm{H}_{10} \mathrm{~N}_{6} \mathrm{O}_{5}$

Yellow solid; IR $\left(\mathrm{KBr}, \mathrm{cm}^{-1}\right): 3374(\mathrm{~N}-\mathrm{H}$, str), 3089 (Ar-CH, str), 2222 (C-N, str), $1600(\mathrm{C}=\mathrm{C}, \mathrm{str}), 1508(\mathrm{C}=\mathrm{N}, \mathrm{str}), 1339(\mathrm{C}-$ $\mathrm{O}-\mathrm{C}, \mathrm{str}), \mathrm{cm}^{-1} ;{ }^{1} \mathrm{H} \mathrm{NMR}\left(\mathrm{CDCl}_{3}, \mathrm{ppm}\right): \delta=$ $3.98\left(\mathrm{~s}(3 \mathrm{H}), \mathrm{CH}_{3}\right), 3.94\left(\mathrm{~s}(3 \mathrm{H}), \mathrm{CH}_{3}\right) 7.264$ $\left(\mathrm{m}(2 \mathrm{H}), \mathrm{NH}_{2}\right), 7.6875(\mathrm{~s}(4 \mathrm{H}), \mathrm{Ar}-\mathrm{H}), 6.96-$ $6.95(\mathrm{~m}(2 \mathrm{H}), \mathrm{Ar}-\mathrm{H}), 7.26-7.20(\mathrm{~s}(1 \mathrm{H}), \mathrm{Ar}-$ $\mathrm{H})$; Mass: $m / z, 418\left(\mathrm{M}^{+}+1\right) ; \mathrm{C}_{21} \mathrm{H}_{15} \mathrm{~N}_{5} \mathrm{O}_{5}$

Yellow solid; IR $\left(\mathrm{KBr}, \mathrm{cm}^{-1}\right)$ : $3374(\mathrm{~N}-\mathrm{H}$, str), 3027 (Ar-CH, str), 2221 (C-N, str), 1600 $(\mathrm{C}=\mathrm{C}, \mathrm{str}), 1508(\mathrm{C}=\mathrm{N}, \mathrm{str}), 1339$ (C-O-C, str) $\mathrm{cm}^{-1} ;{ }^{1} \mathrm{H}$ NMR $\left(\mathrm{CDCl}_{3}, \mathrm{ppm}\right) \delta=3.98(\mathrm{~s}(3 \mathrm{H})$, $\mathrm{CH} 3), 3.94\left(\mathrm{~s}(3 \mathrm{H}), \mathrm{CH}_{3}\right), 7.264\left(\mathrm{~s}(2 \mathrm{H}), \mathrm{NH}_{2}\right)$, 7.68-7.64(m(2H), Ar-H), 7.39-7.37(m $(3 \mathrm{H})$, Ar-H) 6.97-6.95 (m(2H),Ar-H),7.26 (s(1H), Ar-H); Mass: $m / z 373\left(\mathrm{M}^{+}+1\right) ; \mathrm{C}_{21} \mathrm{H}_{16} \mathrm{~N}_{4} \mathrm{O}_{3}$. 
<smiles>COc1ccc(-c2c(C#N)c(N)nc(Oc3ccc(Cl)cc3)c2C#N)cc1OC</smiles>

2-Amino-4-(3, 4-dimethoxyphenyl)-6-(4chlorophenoxy) pyridine-3, 5-dicarbonitrile (4g)<smiles>N#Cc1c(N)nc(Oc2ccccc2)c(C#N)c1-c1cccc([N+](=O)[O-])c1</smiles>

2-Amino-4-(3-nitrophenyl)-6-phenoxy pyridine-3, 5-dicarbonitrile (4h)<smiles>COc1ccc(-c2c(C#N)c(N)nc(Oc3ccc(Cl)cc3)c2C#N)cc1</smiles>

2-Amino-4-(3-methoxyphenyl)-6-(4chlorophenoxy) pyridine-3, 5dicarbonitrile $(\mathbf{4 i})$<smiles>Cc1ccc(-c2c(C#N)c(N)nc(Oc3ccccc3)c2C#N)cc1</smiles>

2-Amino-4-(p-tolyl)-6-phenoxy pyridine-3, 5-dicarbonitrile $(\mathbf{4 j})$
Yellow solid; IR $\left(\mathrm{KBr}, \mathrm{cm}^{-1}\right)$ : 3374(N-H, str), 3027 (Ar-CH, str), 2222 (C-N, str), $1600(\mathrm{C}=\mathrm{C}, \mathrm{str}), 1507(\mathrm{C}=\mathrm{N}, \mathrm{str}), 1372(\mathrm{C}-$ $\mathrm{O}-\mathrm{C}$, str) $\mathrm{cm}^{-1} ;{ }^{1} \mathrm{H}$ NMR $\left(\mathrm{CDCl}_{3}, \mathrm{ppm}\right): \delta=$ $3.99\left(\mathrm{~s}(3 \mathrm{H}), \mathrm{CH}_{3}\right), 3.945\left(\mathrm{~s}(3 \mathrm{H}), \mathrm{CH}_{3}\right), 7.264$ $\left(\mathrm{s}(2 \mathrm{H}), \mathrm{NH}_{2}\right), \quad 7.68-7.64 \quad(\mathrm{~m}(2 \mathrm{H}), \mathrm{Ar}-\mathrm{H})$, 7.39-7.38 (m(2H), Ar-H), 6.97-6.95 $(\mathrm{m}(2 \mathrm{H}), \mathrm{Ar}-\mathrm{H}), 7.26(\mathrm{~s}(1 \mathrm{H}), \mathrm{Ar}-\mathrm{H})$; Mass: $m / 2$ 408-406 $\left(\mathrm{M}^{+}+1\right) ; \mathrm{C}_{21} \mathrm{H}_{15} \mathrm{~N}_{4} \mathrm{O}_{3} \mathrm{Cl}$

Yellow solid; IR $\left(\mathrm{KBr}, \mathrm{cm}^{-1}\right)$ : 3367(N-H, str), 3032 (Ar-CH, str), 2223 (C-N, str), $1613(\mathrm{C}=\mathrm{C}$, str $), 1514(\mathrm{C}=\mathrm{N}, \mathrm{str}), 1449$ (C-O-C, str) $\mathrm{cm}^{-1} ;{ }^{1} \mathrm{H}$ NMR $\left(\mathrm{CDCl}_{3}, \mathrm{ppm}\right)$ : $\delta=7.364 \quad\left(\mathrm{~s}(2 \mathrm{H}), \mathrm{NH}_{2}\right), \quad 8.68-8.64 \quad(\mathrm{~m}(2 \mathrm{H})$, Ar-H), 8.39-8.38 (m(2H),Ar-H), 7.97-7.75 $(\mathrm{m}(5 \mathrm{H}), \mathrm{Ar}-\mathrm{H}), 8.702(\mathrm{~s}(1 \mathrm{H}), \mathrm{Ar}-\mathrm{H})$; Mass: $\mathrm{m} / \mathrm{z} 358\left(\mathrm{M}^{+}+1\right) ; \mathrm{C}_{19} \mathrm{H}_{11} \mathrm{~N}_{5} \mathrm{O}_{3}$

Yellow solid; IR $\left(\mathrm{KBr}, \mathrm{cm}^{-1}\right): 3372(\mathrm{~N}-\mathrm{H}$, str), 3027 (Ar-CH, str), 2222 (C-N, str), $1564(\mathrm{C}=\mathrm{C}$, str $), 1448(\mathrm{C}=\mathrm{N}$, str $), 1440$ (C-O-C, str), $\mathrm{cm}^{-1} ;{ }^{1} \mathrm{H}$ NMR $\left(\mathrm{CDCl}_{3}, \mathrm{ppm}\right)$ $\delta=7.96\left(\mathrm{~s}(2 \mathrm{H}), \mathrm{NH}_{2}\right), 7.96-7.94(\mathrm{~m}(2 \mathrm{H})$, Ar-H), 7.92-7.90 (m(2H),Ar-H), 7.783$7.76(\mathrm{~m}(2 \mathrm{H}), \mathrm{Ar}-\mathrm{H})$, 7.32-7.54 (m(2H), Ar$\mathrm{H}), 3.918\left(\mathrm{~s}(3 \mathrm{H}), \mathrm{CH}_{3}\right)$; Mass: $\mathrm{m} / z \quad 377.5$ $\left(\mathrm{M}^{+}+1\right) ; \mathrm{C}_{20} \mathrm{H}_{13} \mathrm{~N}_{4} \mathrm{O}_{2} \mathrm{Cl}$.

Yellow solid; IR $\left(\mathrm{KBr}, \mathrm{cm}^{-1}\right)$ : $3371(\mathrm{~N}-\mathrm{H}$, str), 3014 (Ar-CH, str), 2231 (C-N, str), $1633(\mathrm{C}=\mathrm{C}, \mathrm{str}), 1416(\mathrm{C}=\mathrm{N}, \mathrm{str}), 1379(\mathrm{C}-$ $\mathrm{O}-\mathrm{C}$, str) $\mathrm{cm}^{-1}$; ${ }^{1} \mathrm{H}$ NMR $\left(\mathrm{CDCl}_{3}, \mathrm{ppm}\right) \delta=$ $7.768\left(\mathrm{~s}(2 \mathrm{H}), \mathrm{NH}_{2}\right), 8.2-7.90(\mathrm{~m}(5 \mathrm{H}), \mathrm{Ar}-$ $\mathrm{H}), 7.487(\mathrm{~m}(2 \mathrm{H}), \mathrm{Ar}-\mathrm{H}), 7.463(\mathrm{~m}(2 \mathrm{H}), \mathrm{Ar}-$ $\mathrm{H}), 2.582 \quad\left(\mathrm{~s}(3 \mathrm{H}), \mathrm{CH}_{3}\right) ; \quad$ Mass: $\mathrm{m} / \mathrm{z} \quad 327$ $\left(\mathrm{M}^{+}+1\right) ; \mathrm{C}_{20} \mathrm{H}_{14} \mathrm{~N}_{4} \mathrm{O}$.

\section{Results and Discussion}

Effect of catalysts on the synthesis of pyridine derivatives

As mentioned in introduction part, several catalysts have been reported for the synthesis of poly substituted pyridine derivatives by the cyclocondensation of aromatic aldehyde, malononitrile and thiophenol in presence of various catalysts have been presented in Table 1 . The reaction time, temperature of the reaction and yield of the corresponding product in presence of nano copper ferrite catalyst has been presented in Table 2. It is observed from 
the literature that the synthesis of substituted pyridines with substituted phenols in presence of nano copper ferrite has not been reported earlier.

Table 1. Effect of catalysts on the synthesis of pyridine derivatives

\begin{tabular}{cccccc}
\hline S.No. & Catalyst & Time & Temp, & Yield, \\
& min & ${ }^{0} \mathrm{C}$ & $\%$ & [Ref.] \\
\hline 1 & Nano crystalline $\mathrm{MgO}$ & 120 & 50 & 64 & {$[21]$} \\
2 & $\mathrm{~K}_{2} \mathrm{CO}_{3}$ & 60 & Reflux & 80 & {$[19]$} \\
3 & Piperidine & 180 & Reflux & 49 & {$[23]$} \\
4 & TBAH (tetra butyl ammonium hydroxide) & 60 & R.T. & 46 & {$[23]$} \\
5 & Ionic liquid (1- $n$-butyl-3- & 70 & R.T. & 92 & {$[20]$} \\
6 & methylimidazolium hydroxide) (bmIm)OH & & R.T. & 52 & {$[22]$} \\
\hline
\end{tabular}

Study of catalytic activity on the synthesis of poly substituted pyridine derivatives

Reaction time, temperature and percentage yield of the products formed when malononitrile reacted with $\mathrm{Ph}-\mathrm{CHO}$ and $\mathrm{Ph}-\mathrm{OH}$ in presence of copper ferrite catalyst.

Table 2. Reaction conditions and yields for the synthesis of poly substituted pyridine derivatives using nano copper ferrite catalyst

\begin{tabular}{ccccccc}
\hline S. No. & R in R-Ph-CHO & R'in R'-Ph-OH & Time, min Temp, ${ }^{0}$ C & Product & Yield, \% \\
\hline 1 & $\mathrm{H}$ & $\mathrm{H}$ & 45 & 50 & $(4 \mathrm{a})$ & 95 \\
2 & $4-\mathrm{OMe}$ & $4-\mathrm{NO}_{2}$ & 40 & 50 & $(4 \mathrm{~b})$ & 96 \\
3 & $4-\mathrm{F}$ & $\mathrm{H}$ & 45 & 50 & $(4 \mathrm{c})$ & 90 \\
4 & $3-\mathrm{NO}_{2}$ & $4-\mathrm{NO}_{2}$ & 55 & 50 & $(4 \mathrm{~d})$ & 88 \\
5 & $3,4-\mathrm{di}\left(\mathrm{OCH}_{3}\right)$ & $4-\mathrm{NO}_{2}$ & 50 & 50 & $(4 \mathrm{e})$ & 90 \\
6 & $3,4-\mathrm{di}\left(\mathrm{OCH}_{3}\right)$ & $\mathrm{H}$ & 55 & 50 & $(4 \mathrm{f})$ & 92 \\
7 & $3,4-\mathrm{di}\left(\mathrm{OCH}_{3}\right)$ & $4-\mathrm{Cl}$ & 45 & 50 & $(4 \mathrm{~g})$ & 96 \\
8 & $3-\mathrm{NO}_{2}$ & $\mathrm{H}$ & 60 & 50 & $(4 \mathrm{~h})$ & 86 \\
9 & $4-\mathrm{Ome}$ & $4-\mathrm{Cl}$ & 50 & 50 & $(4 \mathrm{i})$ & 92 \\
10 & $4-\mathrm{Me}$ & $\mathrm{H}$ & 45 & 50 & $(4 \mathrm{j})$ & 96 \\
\hline
\end{tabular}

Effect of solvent on the synthesis of poly substituted pyridine derivatives

Investigation of reaction medium for the process revealed that solvents played an important role in the reaction under investigation. The results are summarized in Table 3 . It was found that polar solvents such as $\mathrm{CH}_{3} \mathrm{OH}, \mathrm{CH}_{3} \mathrm{CN}$ and $\mathrm{C}_{2} \mathrm{H}_{5} \mathrm{OH}$ were much better than non-polar solvents. Trace amounts of yield observed when $\mathrm{H}_{2} \mathrm{O}$ was used as solvent, presumably due to the aggregation of the hydrophobic catalyst. Although methanol was effective, low yield was obtained when the catalyst was reused. We therefore selected ethanol as solvent. The effect of solvent was checked by the system (4a).

Table 3. Effect of Solvent on the synthesis of poly substituted pyridine derivatives

\begin{tabular}{cccccc}
\hline S.No. & Solvent & Time, min & Temp, ${ }^{0} \mathrm{C}$ & Product & Yield, \% \\
\hline 1 & $\mathrm{H}_{2} \mathrm{O}$ & 80 & 50 & $(4 \mathrm{a})$ & Trace \\
2 & $\mathrm{CH}_{3} \mathrm{CN}$ & 65 & 50 & $(4 \mathrm{a})$ & 45 \\
3 & $\mathrm{CH}_{3} \mathrm{OH}$ & 50 & 50 & $(4 \mathrm{a})$ & 75 \\
4 & $\mathrm{C}_{2} \mathrm{H}_{5} \mathrm{OH}$ & 45 & 50 & $(4 \mathrm{a})$ & 95 \\
\hline
\end{tabular}




\section{Effect of temperature on the synthesis of poly substituted pyridine derivatives}

The reaction temperature has a notable effect on the proposed reaction. The reaction was examined for temperature effect in presence of ethanol as solvent at different temperatures ranging from r.t. to $50{ }^{\circ} \mathrm{C}$. The results are reported in Table 4. It is clear that at lower temperatures, even if the time was increased, only low percentage of yields were obtained. Hence, consequently we chose $50{ }^{\circ} \mathrm{C}$ as the optimal temperature for the reaction.

Table 4. Effect of temperature on the synthesis of poly substituted pyridine derivatives

\begin{tabular}{ccccc}
\hline S.No. & Time, $\min$ & Temp, ${ }^{\circ} \mathrm{C}$ & Product & Yield, \% \\
\hline 1 & 120 & R.T. & $(4 \mathrm{a})$ & 30 \\
2 & 75 & 40 & $(4 \mathrm{a})$ & 65 \\
3 & 45 & 50 & $(4 \mathrm{a})$ & 95 \\
\hline
\end{tabular}

Recycling of the catalyst

Catalyst reusability is of major concern in heterogeneous catalysis. Catalyst recycling was achieved by fixing the catalyst magnetically at the bottom of the flask with a strong magnet, after which the solution was taken off with a pipette, the solid washed thrice with ethyl acetate and the fresh substrate dissolved in the same solvent was introduced into the flask, allowing the reaction to proceed for the next run. The catalyst was consecutively reused five times without any noticeable loss of its catalytic activity. The catalyst is highly magnetic and the saturation magnetization value is found to be $35.56 \mathrm{emu} / \mathrm{g}$, which is much higher than other reported magnetic catalysts. Therefore, it could be easily and almost completely separated by an external magnet which is of a great advantage for a heterogeneous catalyst.

\section{Conclusion}

We have reported an efficient and environmentally benign method for the synthesis of poly substituted pyridine derivatives using nano copper ferrite as catalyst. This method offers several advantages including high yield, short reaction times and ease of separation and recyclability of the catalyst.

\section{Acknowledgement}

The authors wish to thank the University Grants Commission, New Delhi for all the facilities provided through the Major Research Project No. F. 41-371/2012 (SR) to S. Paul Douglas, B. Satyanarayana, UGC-SRF to B. Swathi, CSIR-SRF to M. Ravi Kumar and TEQIP-Phase II research fellowship to K. Jaya Rao.

\section{References}

1. Ramon D J and Miguel Y, Angew Chem Int Ed., 2005, 44, 1602-1634; DOI:10.1002/anie.200460548

2. Domling A, Chem Rev., 2006, 106(1), 17-89; DOI:10.1021/cr0505728

3. Tu S, Jiang B, Zhang Y, Jia R, Zhang J, Yao C and Feng Shi, Org Biomol Chem., 2007, 5, 355-359; DOI:10.1039/B614747J

4. Ma X and Gang D R, Nat Prod Rep., 2004, 21, 752-772; DOI:10.1039/B409720N

5. Perrier V, Wallace A C, Kaneko K, Safar J, Prusiner S B and Cohen F E, Proc Natl Acad Sci., U.S.A., 2000, 97(11), 6073-6078; DOI:10.1073/pnas.97.11.6073

6. Levy S B, Alekshun M N, Podlogar B L, Ohemeng K, Verma A K, Warchol T, Bhatia B, Bowser T and Grier M, U.S. Patent Appl., 2005124678 A1 20050609, 2005. 
7. Anderson D R, Stehle N W, Kolodziej S A, Reinhard E J, PCT Int Appl WO Patent, 2004055015 A1 20040701, 2004.

8. Chem H, Zhang W, Tam R and Raney A K, PCT Int Appl WO Patent, 2005058315 A1 20050630, 2005.

9. Harada H, Watanuk S, Takuwa T, Kawaguchi K, Okazaki T, Hirano Y and Saitoh C, PCT Int Appl WO Patent, 2002006237 A1 20020124, 2002.

10. Beukers M W, Chang L C W, von Frijtag Drabbe Kunzel J K, Mulder-Krieger T Spanjersberg R F, Brussee J and IJzerman A P, J Med Chem., 2004, 47(15), 37073709; DOI:10.1021/jm049947s

11. Chang L C W, von FrijtagDrabbe Kunzel J K, Mulder-Krieger T, Spanjersberg R F, Roerink S F, van den Hout G, Beukers M W, Brussee J and Ijzerman A P, J Med Chem., 2005, 48(6), 2045-2053; DOI:10.1021/jm049597+

12. Fredholm B B, Ljzerman A P, Jacobson K A, Klotz K N and Linden J, Pharmacol Rev., 2001, 53, 527-552.

13. Fletcher M D, Hurst T E, Miles T J, Moody C J, Mishra S and Ghosh R, Tetrahedron., 2006, 62(23), 5454-5463; DOI:10.1016/j.tet.2006.03.051

14. Renslo A R and Danheiser R L, J Org Chem., 1998, 63(22), 7840-7850; DOI:10.1021/jo981014e

15. Thomas A D and Asokan C V, Tetrahedron Lett., 2002, 33(27), 2273-2275; DOI:10.1002/chin.200227184

16. Movassaghi M and Hill M D, J Am Chem Soc., 2006, 128(14), 4592-4593; DOI:10.1021/ja060626a

17. Tanaka K, Mori H, Yamamoto M and Katsumara S, J Org Chem., 2001, 66(9), 30993110; DOI:10.1021/jo005779+

18. Evdokimov N M, Magedov I V, Kireev A S and Konienko A, Org Lett., 2006, 8(5), 899-902; DOI:10.1021/o1052994+

19. Sarita M and Rina G, Synthetic Commun., 2012, 42(15), 2229-2244; DOI:10.1080/00397911.2011.555284

20. Brindaban C, Ranu Ranjan Jana anf Sowmiah S, J Org Chem., 2007, 72(8), 31523154; DOI:10.1021/jo070015g

21. Lakshmi Kantam M, Mahendar K and Suresh B, J Chem Sci., 2010, 122, 63-69.

22. Shaikh Y I, Shaikh A A and Nazeruddin G M, J Chem Pharma Res., 2012, 4(11), 4953-4956.

23. Kai G, Mark J, Thompson and Chen B, J Org Chem., 2009, 74(18), 6999-7006; DOI:10.1021/jo901232b

24. Lakshmi Kantam M, Yadav J, Laha S, Srinivas P, Sreedhar B and Figueras F, J Org Chem., 2009, 74(12); 4608-4611; DOI:10.1021/jo9002823

25. Swapna K, Narayana Murthy S, Tarani Jyothi M and Venkata Durga Nageswar Y, Org Biomol Chem., 2011, 9, 5989-5996; DOI:10.1039/c1ob05597f

26. Daoshan Y, Xiao Z, Wei W, Min J, Ning Z, Dandan R, Jinmao Y and Hua W, Synlett., 2014, 25(5), 729-735; DOI:10.1055/s-0033-1340599

27. Swapna K, Narayana Murthy S and Venkata Durga Nageswar Y, Eur J Org Chem., 2011, 10, 1940-1946; DOI:10.1002/ejoc.201001639

28. Ayoob B, Ghaffar H and Ramin G, ACS Comb Sci., 2013, 15(10), 530-534; DOI:10.1021/co400057h

29. Anil Kumar B S P, Harsha Vardhan Reddy K, Madhav B, Ramesh K and Nageswar Y V D, Tetrahedron Lett., 2012, 53(4), 4595-4599;

DOI:10.1016/j.tetlet.2012.06.077 
30. Kasi Viswanath I V and Murthy Y L N, Chem Sci Trans, 2013, 2(1), 227-233; DOI:10.7598/cst2013.348

31. Paul Douglas S, Santhipriya D, Ramesh Y, Ravi Kumar M, Swathi B and Jaya Rao K, J Chem Sci., 2014, 126(6), 1715-1720; DOI:10.1007/s12039-014-0729-2 